\title{
OBITUARIES
}

\section{Dr. Josephine Macalister Brew, C.B.E.}

IT is hard to believe that Dr. Macalister Brew is dead ; for if any one adjective could have described her it would have been the hackneyed word 'vital'. Of her it was abundantly true, for there can have been few people who have lived so fully, so usefully, or so serviceably.

Her last official job was as education and training adviser to the National Association of Mixed Clubs and Girls' Clubs. But that title gives no idea of the immonse scope of her interests and activities. She was not a dabbler-to her that word was an insult; she was simply a person of such energy and such catholicity of interest that she left untouched no part of tho wide field of the lives of young people. She was not a simple-minded 'do-good-er'. Indeed, her unorthodox methods and rather unusual appearance sometimes frightened, even alarmed, the traditionalists. But she had a remarkable flair for getting inside the skins of the inarticulate young and then assessing what she found by the clear light of charitable reason.

For her intellectual equipment was of a quality quite unusual. She had a robust contempt for the 'starry-eyed' and the 'stuffy' (her own words); she quite simply hated the pompous and the pretentious; and for young people she had a boundless but shrewdly discriminating affection.

It was not surprising that she was worked to death. Government departments, charitable trusts, bodies as varied as the Marriage Guidance Council and the Educational Drama Association all made demands on her strength; and to none of them did she give half-rneasure. What she enjoyed most was not sitting around a committee table but gossiping with boys and girls in a canteon or a 'pub.', and there must be scores of them who remember this odd little figure who knew what they were thinking before they did and, more, could put it into intelligible words.

Josephine Brew made rather shop-soiled words like 'social welfare' or 'youth service' come to life. She never forgot the eternal importance of each single individual human being, and she would never allow generalizations or abstractions to hide the individual boy or girl, puzzled, uncertain, bewildered or lost. She had learming, and in her own field success - the award of a C.B.E. in the Birthday Honours only underlines the melancholy coincidence of her death-and the affection of a multitude of friends. She would prefer to be remembered as one who never lost her astringent affection for hundreds of 'crazy mixed-up kids'. JOHN WOLFENDEN

\section{Dr. J. E. Hamilton, I.S.O.}

James ERIK Hammion, who died suddenly at Stanley, Falkland Islands, on April 15, a few weeks before his sixty-sixth birthday, had spent more than thirty years in the Falkland Islands and their Dependencies. After graduating at the University of Liverpool in 1913, he spent the summers of 1913 and 1914 at Blacksod Bay, Co. Mayo, on behalf of the Committee of the British Association appointed to investigate the biological problems incidental to the Belmullet whaling station. In 1914 he took his M.Sc. degree, specializing in oceanography, and occupied junior teaching posts at King's College, London, and The Queen's University, Belfast, until 1916, when he joined the R.A.M.C. as bacteriologist. In 1919 he was appointed to be Government naturalist and magistrate in the Falkland Islands, a post he occupied for thirty years until his retirement in 1949. For half this period, from 1924 until 1939, he was seconded to the scientific staff of the Discovery Investigations, and served in the ships belonging to the Discovery Committee, in the Marine Station at South Georgia, and in England. During the Second World War he was in the Falkland Islands and acted as registrar general and registrar of the Supreme Court, as well as being a police magistrate at Stanley and a temporary member of the Legislative Council. He was awarded the Polar Medal in 1943, and appointed a Companion of the Imperial Service Order in 1948.

Hamilton was a good field naturalist and was particularly interested in marine mammals and birds, on which he published a number of papers in various scientific journals. His most important published work is contained in two papers on the southern sea lion that appeared in Discovery Reports in 1934 and 1939 , and formed the main part of the material for which his doctorate was conferred. During his residence in the Dependencies he had the opportunity for collecting much rare cetacean material and enriched the collections of the British Museum (Natural History) by presenting many valuable skulls and skeletons of the southern dolphins, which are generally very poorly represented in museum collections. In addition, he sent home large collections of skulls from several species of southern seals, specimens which are of unusual value as they are accompanied by very full data. After his retirement in 1949 Hamilton continued to reside in the Falkland Islands, where he carried on with his collecting and zoological work. $\mathrm{He}$ was particularly concerned for the preservation of the stocks of whales, which he considered were being dangerously over-fished, and stated his views in several outspoken contributions in Nature during recent years.

Hamilton was of medium height and stocky build, and enjoyed the rough conditions of life that he experienced on many of his expeditions in the course of the Discovery investigations, as well as during his work as Government naturalist. The latter took him into some very remote places in company with the sealers and whalers, among whom he had many friends. In 1931 he married Miss Rose Purdie, who survives him, and to whom we extend our sympathy.

\section{Harrison Matthews}

\section{Dr. J. F. Allan}

DR. J. F. ALLAN, superintendent of the Ship Division, National Physical Laboratory, collapsed and died on June 8 while sailing on holiday at Aldeburgh, Suffolk.

James Foggo Allan was born on July 23, 1904, at Brechin, Angus, the son of a Church of Scotland minister. He was educated at Dumbarton Academy and the University of Glasgow, and served an apprenticeship with William Denny and Bros., Ltd., the 
Dumbarton shipbuilders. He held the Sir William White Rasearcl Scholarship of the Institution of Naval Architects during 1927-29. In 1948, ho was awarded the degree of D.Se. by the University of Glasgow for his pioneer work in the development of ship roll stabilizers, now a familiar feature of many passenger ships.

From 1926 until 1948 he was on the staff of the ship model expэriment tank at Dumbarton; during thy last six years of this period he was in charge of the department. In 1948, he was appointed superintendent of thə Ship Division of the National Physical Laboratory.

Since Dr. Allan's appointment, the Division has considerably widened its range of activities and, under his enthusiastic guidance, the new National Physical Laboratory Ship Hydrodynamics Laboratory at Feltham was planned and construction begun. In this Laboratory the work of the Division in carrying out experiments for ship-builders on new designs and in basic research into the hydrodynamic problems of ships will be continued in the ways in which he so firmly believed.

Dr. Allan was an international figure in the world of naval architecture; he served on many committees and published a number of notable papers. He was a member of Council of the Institution of Naval Architects and of the Scholarships and Publications Committee. He took a leading part in the organization of the triennial International Towing Tank
Conference (formerly International Conference of Ship Tank Superintendents), serving on the Conference Standing Committee, and was an active member of several British Shipbuilding Research Association technical committees, acting as chairman of the Propulsion Sub-Committee. The papers which Dr. Allan published dealt with many different ship design problems, including scale effects on propellers and shaft supports, the resistance of barges, hull forms for drifters, and the comparison of ship-trial results with model predictions. His paper on "The Stabilization of Ships by Activated Fins" was awarded a premium of the Institution of Naval Architects in 1945, and that dealing with "The Effect of Roughness on Ship Resistance", which he presented jointly with Mr. R. S. Cutland to the North East Coast Institution of Engineers and Shipbuilders last year, gained the M. C. James Medal.

In addition to the work described in these papers, Dr. Allan was actively engaged during the Second World War on the development of a high-speed hydrofoil-supported torpedo boat, and at the time of his death was vigorously developing new ship features. His loss will be keenly felt, not only at the National Physical Laboratory but also in shipbuilding circles throughout the world. It is particularly tragic that his services will not be available at the time when the new ship research laboratory, one of the most comprehensive in the world, is to be put into operation.

\section{NEWS and VIEWS}

\section{Royal Society of Edinburgh : New Fellows}

THe following have been elected Honorary Fellows of the Royal Society of Edinburgh : Dr. H. J. Bhabha, chairman, Atomic Energy Commission of India, Bombay; Sir Alexander Fleck, director, Imperial Chemical Industries, Ltd. ; Dr. R. J. Heim, director, Museum of Natural History, Paris ; Prof. Olaf Holtedahl, professor of historical geology in the University of Oslo ; Sir Rudolph Peters, professor emeritus of biochemistry in the University of Oxford ; Prof. C. E. Tilley, professor of mineralogy and petrology in the University of Cambridge.

\section{Mathematics in the University of Manchester:} Prof. G. J. Kynch

Prof. Georae James KYNCH, at present professor of applied mathematics in the University College of Wales, Aberystwyth (see Nature, 169, 266 ; 1952), has been appointed to the new chair in mathematies in the faculty of technology in the University of Manchester. Prof. Kynch graduated at the Imperial College of Science and Technology with honours in physics in 1935. He then read for honours in mathematics and obtained a first-class degree in the following year, together with a University prize and research scholarship. He obtained the Ph.D. and the diploma of the Imperial College in mathematics in 1939. His research on valence theory and magnetism at" the Imperial College during 1936-40 was under the direction of Dr. (now Sir) William Penney. Dr. Kynch was appointed to a lectureship at the University of Birmingham under Prof. R. E. Peierls, and also undertook part-time research as a member of the Ministry of Supply "Tube Alloys" team at the University of Birmingham. Since 1952 he has been professor of applied mathematics in the University College of Wales, Aberystwyth. Prof. Kynch will take up his duties at Manchester in September.

\section{Chemistry at Auckland University College : \\ Prof. D. R. Llewellyn}

Dr. Đ.R. LLEWELLYN, who has recently been appointed professor of chemistry at Auckland University College, New Zealand, graduated with first-class honours in chernistry from the University of Birmingham in 1941. During 1941-44 he carried out research under the direction of the late Prof. $F$. Simon at Oxford, where he obtained the D.Phil. degree, and in the following year he went as a research assistant in the Cavendish Laboratory, Cambridge. His university teaching work on a fulltime basis started in the University College of North Wales in 1945, when Prof. E. D. Hughes held the chair of chemistry at Bangor. Llewellyn was a lecturer there until 1949, when he was appointed to an Imperial Chemical Industries fellowship, tenable at University College, London, where he became a lecturer in 1952.

Dr. Llewellyn's published work has dealt with the chemistry of uranium, the preparation of stable isotopes by fractional distillation, and the use of various tracers in the study of the mechanism of reactions. In 1952, he was awarded the Weizmann Prize for a paper on the separation of isotopes, published in collaboration with Drs. I. Dostrovsky and J. Gillis. He has shown marked ingenuity in the design and construction of physical apparatus, especially large-scale distillation columns of high efficiency. His natural aptitude in this direction was, no doubt, fostered when he worked as a physical 